\title{
EVALUATION OF RESULTS IN CHOSEN SUBJECTS AND ANALYSIS OF THE MOTIVATION OF DISTANCE STUDENTS
}

\begin{abstract}
The university studies of adult people in the combined or distance form of study denote many differences in comparison with the regular studies. Very important question is if the results of the distance students are on the same level as those of regular students. The Czech University of Life Sciences in Prague has steadily high number of combined students in tutorial centres outside Prague. The contribution is based on an inquiry survey among the students of tutorial centres. Another data source is the official database of the university. The level of satisfaction of students was compared with their results and a negative dependency was found. We also investigated the relation between socio demographic characteristics and the motivation and attitude to the study. We found dependencies in two questions. Finally, we compared the results of the students from the tutorial centres and regular students and have not found remarkable differences. The good (not worse) results of students from the centres of distance studies can be explained by more intensive motivation which implies more intensive and more responsible preparation for exams. For the statistical analysis we used the software SPSS, version 18.
\end{abstract}

\section{Key Words}

Course assessment, subjective and objective evaluation, distance students, inquiry survey, statistical analysis, categorical data

\section{Hana Vostrá Vydrová, Andrea Jindrová, \\ Ludmila Dömeová \\ Czech University of Life Sciences Prague \\ vydrova@pef.czu.cz}

ARTICLE INFO

Article type

Full research paper

doi: 10.7160/eriesj.2012.050104

Article history

Received: November 28, 2011

Received in revised form: February 20, 2012

Accepted: February 23, 2012

Available on-line: March 31, 20112

Vostrá Vydrová, H., Jindrová, A., Dömeová, L. (2012) “Evaluation of Results in Chosen Subjects and analysis of the Motivation of Distance Student", Journal on Efficiency and Responsibility in Education and Science, Vol. 5, No. 1, pp. 36-45, ISSN 1803-1617, [on-line] www.eriesjournal.com/_papers/article_166.pdf [2012-03-31]. doi: 10.7160/eriesj.2012.050104 


\section{Introduction}

The article follows from the work of authors which was published as a contribution of the conference ERIES 2011. The contribution was extended by further dissemination of the introductory part of the question form. This part is concerned with the motivation of the adult students for further studies and improvement of their education level.

The Czech University of Life Sciences in Prague has 26317 students in regular and combined form of study during the academic year 2010/2011 (Faculty of Economics and Management 13132 students in regular and combined form of study). Major part of the combined students is in the tutorial centres out of the Prague. The number of these students is steadily high, with growing tendency in particular places. The continuous interest of adult students inspired the authors for seek for the motivation for further education in the combined form of study. The comparison of study results of regular and combined students is also included.

The quality of education at universities is traditionally evaluated by study results of students or graduates. Important information for graduates is the percentage of employed on appropriate posts.

The results of students can be measured not only by the examination grades but also by the subjective satisfaction of students. The evaluation by students represents important source of information for teachers and the universities' management. The feedback from students to teachers helps to improve the quality of education process. The source of students' estimations can be a survey.

The evaluation of teaching is provided in all developed countries. Regular enquiries take place regularly at universities in the US, Canada and Western Europe since the seventieth (Berk, 1979).

Distance learning is a new trend in education. One of the attractions of distance learning is its flexibility of instruction. Since students and instructors can be separated spatially and temporally from each other, students in a remote area and parttime students can all benefit from this spatial-temporal flexibility as well as a high degree of information sparing (Chang, 2002). New communication technology, such as the internet, has been widely introduced in order to reach those who are unable to enrol at conventional universities. By way of such technology, students are supposed to be able to study wherever and whenever they want, and thereby gain the flexibility necessary for conducting their studies (DePew, Lettner-Rust, 2009).

The learning management systems, e-learning courses and blended learning tools are often evaluated and the recognized effectiveness is very important for their improvement and development. E-Learning systems are multidisciplinary by nature. Many researchers from fields as computer science, information systems, psychology, education, and education technology, have been trying to evaluate e-learning systems (Eccles, 1991).

Generally, there are two main streams of assessment the e-learning systems: e-Learning system as a social entity; e-Learning system as a technical entity (Ozkan, Koseler, 2009).

The social issues often do not have proper importance. In webbased educational systems the structure of learning domain and content are usually presented in the static way, without taking into account the learners' goals, their experiences, their existing knowledge, their ability (known as insufficient flexibility), and without interactivity (means there is less opportunity for 
receiving instant responses or feedbacks from the instructor when learners need support) (Baylari, Montazer, 2008).

The two main orientations can be specified in more groups. Ozkan, Koseler (2009) proposed an investigation based on six main entities, learners attitudes, instructor quality, system quality, information (content) quality, service quality, and supportive issues. The assessment of the e-learning system they made only using the students perceptions.

In our research we focused on the social issues and we tried to find relations between subjective views of students and their objective results.

We propose a pilot survey which is focused on the students from centres of distance studies (CDiS) of the Czech University of Life Sciences (CULS Prague), Faculty of Economics and Management (FEM). The students evaluated their courses from the point of view of the personal social profitability, as a support of their professional career and possible application in practice. Dependency between the subjective evaluation of the subject and the final grade was investigated. Also the results of distance students from the CDiS and regular students from Prague were compared. The analysis was based on comparison of average grades in several subjects. The results have been evaluated by the analysis of categorial data based on frequency distribution. The first part of the question form was afterwards distributed to another students of CULS Prague. The goal was to get bigger sample for dependency analysis. To the extended data file the analysis of categorial data (in the form of association and contingency tables) was applied.

\section{Material and Methods}

The target group of the survey consists of the students of the branch Operation and Administrative in the CDiS in Hradec Králové. The inquiry form has two parts. The first part contains questions necessary for getting identification data and questions focused on the reasons and motivation for study. In the second part the students evaluate several courses which they have attended and point out their final grade.

The distribution of the first part of the question form to another students brought large data file which enables more precise analysis. The information on the motivation for study is then of a higher quality. The question form was distributed among the students of the second and third year in the centre Hradec Králové.

For the analysis of the survey we use single dimensional and multiple dimensional analyses of categorical data. The basic analysis contains frequency distribution and calculations of describing characteristics. For searching for relations between two variables we use contingency tables.

For the tests in the contingency tables we use Chi square test to not reject the independence of variables. The construction of the measure of the intensity of relations used Pearson's contingency coefficient $(\mathrm{Cp})$. If the conditions for Chi square test are not fulfilled the Fisher exact test is applied. A single selection test on mean value $\mu$ proved if certain average grade of sample file of students is equal to certain value or not. This test enables us to prove the hypothesis that the average $\mu$ of the basic file is equal to certain constant value. The null hypothesis is: $\mathrm{H}_{0}: \mu=\mu_{0}$. The decision is made using $p$-value (p) and significance level $\alpha$. The statistically significant differences are proved when $\mathrm{p}<\alpha$. For assessment if there is a dependency between subjective view of 
the student and his or her final grade we use Pearson correlation coefficient (r). Due to a high number of courses included in the survey we decided to aggregate them into 3 subjects groups:

Group 1 (8 subjects): Mathematics I, Informatics I, Informatics II, Statistics I, Mathematical Methods, Economics I, Economics II, Cybernetics.

Group 2 (4 subjects): Basic phytotechnics, Special phytotechnics, Animal husbandry I, Animal husbandry II.

Group 3 (8 subjects): Science, philosophy and society, Foreign language I, Foreign language II, Psychology of personality and communication, Agriculture goods appraisement, Psychology and ethics of entrepreneurship, Basis of legal theories.

The relations between the subjective evaluation of students and the final grade have been investigated in a correlation matrix. The data from survey were analysed using the Statistical Package for the Social Sciences (SPSS), version 18. The significance level was set as $\alpha=0,05$. The data come from a normal distribution.

\section{Results and Discussion}

\section{Description of the pilot sample}

A pilot study was applied to 40 undergraduate students (the total number of enrolled students in the class was 56), 2nd year, from the CDiS Hradec Králové, 85 \% were females, $15 \%$ males. The percentage of female students is typical for the CDiS. While there are approximately $60 \%$ of female students in the regular form, the percentage in all CDiS is higher (Vydrová et. al., 2010). The most frequent age group was 28-37 (see Fig.1). 48 and more was only in one case and that's why recoded for further analysis. This variable has been defined with only three categories: age groups 18-27, 28-37, 38 and more.

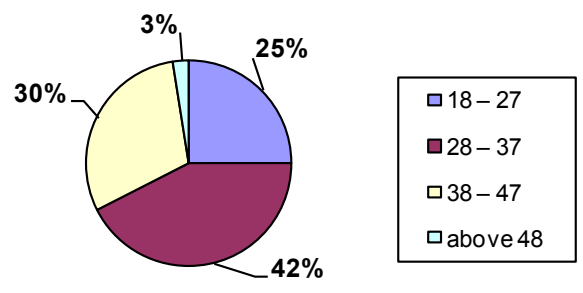

Figure 1: The age structure of survey responders

Another question focused the sector of employment. The highest number of responders ( $85 \%$ ) is now employed in the tertiary sector; mainly in services and state administration. $10 \%$ are employed in the industrial sector and only $5 \%$ works for the primary sector (agriculture, mining, etc.). The file distribution according the domicile is in the Table 1.

\begin{tabular}{|l|c|c|c|}
\hline Intervals & Number & $\%$ & Cumulative \% \\
\hline Under 4 999 inhabitants & 15 & 37.5 & 37.5 \\
\hline $5000-19999$ inhabitants & 9 & 22.5 & 60.0 \\
\hline $20000-99999$ inhabitants & 8 & 20.0 & 80.0 \\
\hline 100000 and more & 8 & 20.0 & 100.0 \\
\hline Total & 40 & 100.0 & \\
\hline
\end{tabular}

Table 1: The size of place of living according to the number of inhabitants

The attitude towards the self study has been also investigated. Relatively high number (55\%) of students stated that they prepare continuously with the same intensity to each subject. The self study was reduced only to working on dated up tasks in $30 \%$ and $12.5 \%$ of respondents is working only to get though to go ahead to higher class. Only one respondent is working only in subjects which are interesting for him. 
These results are very different from answers of regular students in an investigation made a couple years before by Poláčková, Jindrová (2010). The work only in the framework of compulsory task stated $62.3 \%$ and $20 \%$ of students work only in subjects which are interesting for them. $15 \%$ spend only a minimal labour on self study and only $3.8 \%$ is preparing from one lesson to another (i.e. each week).

These differences can be explained by higher motivation of the adult students. Quite often they have to reach the university degree to keep and/or improve their position at work. Successful termination of the university studies has a great importance for them not only in their professional development but also for their private social status. These might be the reasons for more intensive self study and higher responsibility.

\section{Extended file with more respondents}

Another group of combined students filled the first part of the question form. This part is concerned with the motivation for study and overall attitude. The part with concrete results of subject was left out. The question forms were filled in anonymous. In total 106 questionnaires were evaluated.

The gender differentiation of responders was: $33 \%$ men, $67 \%$ women. The age group 28-37 was the most frequent. Other age groups had $24,5 \%$ (18 - 27 years), 29,2 \% (38-47 years), 3,8\% (48 and more) (see Tab. 2). The group of students over 48 was the smallest.

\begin{tabular}{|c|c|}
\hline Age group & Total percentage \\
\hline 18-27 years & 24,5 \\
\hline $28-37$ years & 42,5 \\
\hline $38-47$ years & 29,2 \\
\hline 48 and more & 3,8 \\
\hline
\end{tabular}

Table 2: Age structure of respondents
The distribution according the job sector of the responders' is following: $5.7 \%$ work in the primary sector; $19.8 \%$ in the secondary sector and $74.5 \%$ in the tertiary sector (most frequent answer).

It follows from the attitude to the study (see Tab. 3) that $59.4 \%$ of respondents study continuously and evenly in all subjects.

\begin{tabular}{|c|c|}
\hline What is your attitude to study? & $\begin{array}{c}\text { Total } \\
\text { percentage }\end{array}$ \\
\hline $\begin{array}{c}\text { I study continuously in all subjects evenly } \\
\text { interesting for me }\end{array}$ & 59.4 \\
\hline I study continuously only in subjects which are & 6.6 \\
\hline I do some work only in projects or assigned tasks & 22.6 \\
\hline I do minimum work necessary for passing to next \\
year
\end{tabular}

Table 3: What is your attitude to study?

The motivation of students was investigated by following question. The question offered several statements and the answer could be chosen from: yes, I agree - I partly agree - I partly disagree - I disagree. The values in brackets correspond with data obtained in the pilot survey. For the statement "motivation for the study in the CDiS is non-admission to the regular form of study":

- $63.2 \%(77.5 \%)$ disagree or partly disagree,

- $18.9 \%(7.5 \%)$ agree,

- $17.9 \%(15 \%)$ partly agree. 
The reverse frequency of answers was for the statement "the university graduation is necessary for present work of the respondent":

- $73.6 \%(77 \%)$ agree or partly agree,

- $6.6 \%(10 \%)$ partly disagree,

- $19.8 \%$ (12.5\%) disagree.

Getting better working place is a motivation for $84.9 \%$ (90\%) of students. $15.1 \%$ (10\%) disagree or partly disagree. The share of reaction to the claim "I want to widen my knowledge" was similar to the previous. $93.4 \%$ (90\%) of respondents agree or partly agree.

The final two statements are connected with the social status and finding new friends and contacts. More than one half (62.3 $\%\{55 \%\})$ answered that "they wish to improve their position in the view of their families and friends"; disagree $28.3 \%$ (32.5\%). New friends of contacts wish to find $67.9 \%(70 \%)$ of students. This is not a motivation for $32.1 \%(28 \%)$.

The most remarkable difference between the pilot and extended survey is in the question "motivation for the study in the CDiS is non-admission to the regular form of study"; in the answer "agree" where the difference is more than $10 \%$. The most similar answers are in the question "I want to widen my knowledge".

\section{Dependency analysis: pilot study}

In the analysis of dependencies of two variables we analyse the question in which we suppose some kind of logical consequence. We analysed the dependency between the attitudes towards the self study and the socio demographic signs. No dependencies were proved. It means that the gender (the same results in Vydrová et. al., 2010), place of living, age or employment do not have any remarkable influence to the attitude to study.
We investigated also the possible dependencies of motivation and gender, age and sector of employment. The only dependency was proved in relation of gender and motivation for study: "My goal is to get better working place" $(\mathrm{p}<0.021)$. The dependency in this case was medium $\left(C_{p}=0,477\right)$. It follows from the contingency table that $50 \%$ of female responders agree, $44.1 \%$ agree partly and total $5.8 \%$ disagree or partly disagree. For male responders, $66.7 \%$ partly agree and disagree $33.3 \%$.

\section{Dependency analysis: extended file}

The first analysis dealt with dependency of the age and gender and the attitude to the study.

The dependency between the gender and the attitude was proved by Chi square test and the Pearson's contingency coefficient as existing with medium weight $(\mathrm{Cp}=0.384)$. It follows from the contingency table the $70.4 \%$ of women study continuously in all subjects. The same attitude presented only $37.1 \%$ of men. Generally, the male students more frequently prefer some interesting subjects and work only on assessed tasks and projects. There is no proved relation between the gender and the attitude to the study.

Another question dealt with the motivation for study. The relations to the gender are in Tab. 4; the relations to the age are in Tab. 5. The statistical important dependency was proved only for the gender and motivation "find new friends and contacts" $(\mathrm{Cp}=0.330)$ and between the age group and the reason "not accepted for the regular form of study" $(\mathrm{Cp}=0.466)$. The younger respondents (18-27 years) had chosen the combined study prevailingly because they were not accepted for the regular studies. On the other hand the older age groups usually disagree with this reason. For further specification - see results of testing of contingency tables in Tab. 4 and Tab. 5 . 


\begin{tabular}{|c|c|c|c|}
\hline $\begin{array}{c}\text { What is your motivation for } \\
\text { study? }\end{array}$ & $\begin{array}{c}\text { Dependency } \\
\text { on gender } \\
\text { exists }\end{array}$ & $\mathrm{p}$-value & $\begin{array}{c}\text { Pearson's } \\
\text { coefficient }\end{array}$ \\
\hline $\begin{array}{c}\text { I want to finish my study (has not } \\
\text { been accepted to regular form, has } \\
\text { not finished previous study). }\end{array}$ & no & $\mathrm{p}<0.667$ & \\
\hline $\begin{array}{c}\text { The university graduation is } \\
\text { necessary for keeping my job. }\end{array}$ & no & $\mathrm{p}<0.233$ & \\
\hline I want to get better job. & no & $\mathrm{p}<0.136$ & \\
\hline I want to extend my knowledge. & no & $\mathrm{p}<0.156$ & \\
\hline $\begin{array}{c}\text { I want to improve my value for } \\
\text { my family and friends }\end{array}$ & no & $\mathrm{p}<0.942$ & \\
\hline $\begin{array}{c}\text { I want to find new friends and } \\
\text { contacts. }\end{array}$ & yes & $\mathrm{p}<0.005$ & 0.330 \\
\hline
\end{tabular}

Table 4: Summarizing table of dependencies between gender and motivation

\begin{tabular}{|c|c|c|c|}
\hline What is your motivation for study? & $\begin{array}{c}\text { Dependency } \\
\text { on age } \\
\text { exists }\end{array}$ & p-value & $\begin{array}{c}\text { Pearson's } \\
\text { coefficient }\end{array}$ \\
\hline $\begin{array}{c}\text { I want to finish my study (has not } \\
\text { been accepted to regular form, has not } \\
\text { finished previous study) }\end{array}$ & yes & $\mathrm{p}<0.001$ & 0.466 \\
\hline $\begin{array}{c}\text { The university graduation is } \\
\text { necessary for keeping my job. }\end{array}$ & no & $\mathrm{p}<0.141$ & \\
\hline I want to get better job & no & $\mathrm{p}<0.212$ & \\
\hline I want to extend my knowledge. & no & $\mathrm{p}<0.235$ & \\
\hline $\begin{array}{c}\text { I want to improve my value for my } \\
\text { family and friends }\end{array}$ & no & $\mathrm{p}<0.542$ & \\
\hline I want to find new friends and \\
contacts & no & $\mathrm{p}<0.213$ & \\
\hline
\end{tabular}

Table 5: Summarizing table of dependencies between age and motivation

\section{Evaluation of grades}

The exam is both written and oral. The examination questions are on the same level for regular and combined students. The grades are from 1 (the best) to 4 (the worst, not acceptable). Even though the number of contact lessons is different all students must cope with the same volume of topics and manage the exam on the same qualitative and quantitative level. The regular students have 12 lectures (1.5 hour each) and 12 seminars (1.5 hour each); totally 36 hours of contact learning. The combined students have an intensive tutorial in two days for one subject; totally 16 hours.

The results of comparison of the results of distance students from the tutorial centres and regular students from Prague are in the following text. The study plans and syllables are of course is approximately the same? We investigated the results of the same branch of study (Operation and Administrative). The comparison has been made using the average grades of the regular students (reference constant) for the group of subjects (three groups see above). Tab. 6 shows that there is no statistically important difference between the average grade of regular (all students, included, official data from study department of the FEM) and combined students - responders of the survey.

\begin{tabular}{|l|c|c|c|}
\hline & $\begin{array}{c}\text { Reference } \\
\text { constant }\end{array}$ & $\begin{array}{c}\text { Average grade } \\
\text { in the CDiS }\end{array}$ & p-value \\
\hline 1. Group & 2.03 & 2.80 & $\mathrm{p}<0.867$ \\
\hline 2. Group & 1.80 & 2.53 & $\mathrm{p}<0.981$ \\
\hline 3. Group & 1.56 & 2.09 & $\mathrm{p}<0.896$ \\
\hline
\end{tabular}

Table 6: Comparison of average grades in three groups of subjects

Because further on we work only with groups of subjects we search also for differences inside these groups. We compared 
the results of single subjects (see table 7). It is possible to find subjects which have different grade than the average grade of the group of subjects.

\begin{tabular}{|c|c|c|c|c|c|c|c|}
\hline \multicolumn{4}{|c|}{$\begin{array}{l}\text { Important differences between grades in } \\
\text { subject and in group }\end{array}$} & \multicolumn{4}{|c|}{ No important differences } \\
\hline $\begin{array}{l}0 \\
0 \\
0\end{array}$ & Subject & $\begin{array}{l}\text { Ref. } \\
\text { const. }\end{array}$ & p-value & $\begin{array}{l}0 \\
0 \\
0 \\
0\end{array}$ & Subject & $\begin{array}{l}\text { Ref. } \\
\text { const. }\end{array}$ & p-value \\
\hline 1 & Mathematics & 2.000 & $\mathrm{p}<0.001$ & 1 & Cybernetics & 2.180 & $p=0.173$ \\
\hline 1 & Informatics II & 1.692 & $\mathrm{p}<0.001$ & 3 & $\begin{array}{c}\text { Basis } \\
\text { of legal } \\
\text { theories }\end{array}$ & 1.436 & $p=0.275$ \\
\hline 3 & $\begin{array}{l}\text { Agriculture } \\
\text { goods } \\
\text { appraisement }\end{array}$ & 1.079 & $\mathrm{p}<0.001$ & 3 & $\begin{array}{c}\text { Psychology } \\
\text { of } \\
\text { personality }\end{array}$ & 2.154 & $\mathrm{p}=0.850$ \\
\hline 3 & $\begin{array}{l}\text { Psychology } \\
\text { and ethics }\end{array}$ & 1.718 & $\mathrm{p}<0.002$ & & & & \\
\hline
\end{tabular}

Table 7: Comparison of average grades of those subjects where the dependency between subjective evaluation and grade was proved

The table contains only the subjects where the dependency between evaluation by students and final grades is found. These subjects are in table 8 .

The students' evaluation came from the survey. The students had to evaluate each subject from their point of view (both the evaluation of the subject and the teacher). The normal distribution of data in this data set was proved.

\begin{tabular}{|l|c|}
\hline Subject & $\mathrm{r}$ \\
\hline Mathematics & -0.325 \\
\hline Informatics II & -0.439 \\
\hline Psychology of personality & -0.381 \\
\hline Agriculture goods appraisement & -0.331 \\
\hline Cybernetics & -0.447 \\
\hline Psychology and ethics & -0.393 \\
\hline Basis of legal theories & -0.561 \\
\hline
\end{tabular}

Table 8: Correlation coefficients for chosen subjects
The final part of the analysis deals with the dependency between the subject evaluation and the final grade. Tab. 8 contains statistically important Pearson correlation coefficient in cases with at least medium dependency proved. The strongest dependency is for the subject "Basis of legal theories"; $r=-0,561$. The indirect correlation appears for all subjects what means indirect dependency, i.e. the grade is not in line with the subjective evaluation of the student. For example, the student was satisfied with the course but underestimated the preparation for the exam and the final grade is bad and vice versa.

\section{Conclusion}

The article represents a continuance of the authors work on investigation of the combined studies in the CDiS and follows already published works (e.g. Vydrová et. al., 2010), (VostráVydrová at. al., 2011).

Firstly, the data from the pilot survey were collected and analysed. For improving the quality and reliability of the obtained information the number of responders was extended. The second group of students filled only the first part of the question form dealing with the motivation for study. The analysis of the motivation is in the chapter "Results and Discussion".

The attitudes to the study and the motivation were investigated only for the combined students.

Some important dependencies between answer to these questions and the socio demographic characteristics of the responder were found. 
The dependencies between characteristic age and gender and the motivation of study were found for questions:

- I want to find new friends and contacts. - Dependency on gender.

- I want to finish my study (has not been accepted to regular form, has not finished previous study). - Dependency on age.

The survey proved relations between subjective evaluation of particular course and the final grade. The relations were indirect, i.e. subjective satisfaction with the course leads to a worse final grade. The reason is probably in undervaluation of preparation for exam in those subjects that seem to be easy and understandable for the student.

In the comparison of regular and combined students, the differences were found in the average grades in particular subjects but no statistically important differences were proved in comparison of groups of subjects.

\section{Acknowledgements}

The paper is supported by the grant project of the Ministry of Education of the Czech Republic No. MSM6046070904 - "Information and Knowledge Support of Strategic Management".

\section{References}

Abbot, R. D., Perkins, D. (1982) "Reliability and Validity Evidence for Scales Measuring Dimensions of Student Rating of Instruction", Educational and Psychological Measurement, Vol. 42, pp 563-569.

Baylari, A., Montazer, Gh. A. (2009) “Design a personalized e-learning system based on item response theory and artificial neural network approach", Expert Systems with Applications, Vol. 36, No. 4, pp 8013-8021.

Berk, R. A. (1979) "The Construction of Rating Instruments for Faculty Evaluation", Journal of Higher Education, Vol. 50, No. 5, pp 650-669.

Chang, F. C. (2002) "Intelligent assessment of distance learning", Information Science, Vol. 140, No. 1-2, pp 105-125.

Depew, K. E., Lettner-Rust H. (2009) "Mediating Power: Distance Learning Interfaces, Classroom Epistemology, and the Gaze", Computers and Composition, Vol. 26, No. 3, pp 174-189.

Dömeová, L., Beránková, M., Houška, M. (2010) “Computer supported knowledge in distance learning", In Proceedings of 2 nd International Conference on Software Technology and Engineering ICSTE 2010, San Juan: 2010, pp 181-184.

Eccles, R. G., (1991) “The performance measurement manifesto", Harvard Business Review, Vol. 69, No. 1, pp 131-137.

Marsh, H. W. (1985) "Students' evaluations of university teaching: Dimensionality, reliability, validity, potential biases, and utility", Journal of Educational Psychology, Vol. 76, No. 5, pp 707 - 754 .

Overall, J. U., Marsh, H. W. (1980) “Students' Evalutions of Instruction : A Longitudinal Study of Their Stability", Journal of Educational Psychology, Vol. 72, No. 3, pp 321-325. 
Ozkan, S. I., Koseler, R. (2009) "Multi-dimensional students' evaluation of e-learning systems in the higher education context: An empirical investigation", Computers \& Education, Vol. 53, No. 4, pp 125-129.

Poláčková, J., Jindrová, A. (2010) “Innovative approach to education and teaching of statistics", Journal on Efficiency and Responsibility in Education and Science An international peerreviewed journal published by Faculty of Economics and Management Czech University of Life Sciences Prague, Vol. 3, No. 1, pp 14-27.

Rezanková, H. (2007) Analysis of data from the survey. Professional Publishing Praha, pp 228. (in Czech)

Vostrá-Vydrová, H., Jindrová, A., Dömeová, L. (2011) “The attitude of adult students towards particular subjects, their motivation and results", In Proceedings of the international conference ERIE 2011, Czech University of Life Sciences Prague: 2011, pp 341-350.

Vydrová, H., Dömeová, L., Jindrová, A. (2010) “Women in distance studies", In Proceedings of the international conference ERIE 2010, Czech University of Life Sciences Prague: 2010, pp 275-282. 